J. Clin. Chem. Clin. Biochem.

Vol. 25, 1987, pp. 77-82

(C) 1987 Walter de Gruyter \& Co.

Berlin · New York

\title{
Effect of Parathyroid Hormone on the Fragility and Enzyme Activities of Red Blood Cells from Young and Mature Rabbits)
}

\author{
By E. Bogin, Z. Malachi, M. Djaldeti and J. Levi
}

Department of Biochemistry, Kimron Institute, Bet Dagan, Israel

and

Department of Nephrology and Medicine „B", Hasharon Hospital, Petah Tiqva, Israel

Tel Aviv University Medical School, Tel Aviv, Israel

(Received December 21, 1985/September 25, 1986)

Summary: The effect of parathyroid hormone on erythrocytes from newborn and adult rabbits was studied in relation to the fragility pattern in hypotonic salt solutions and the activities of $\mathrm{Ca}$ - and $\mathrm{Mg}$-dependent ATPases. Median osmotic fragility of red blood cells from newborn rabbits was significantly higher than in red blood cells from mature rabbits. Parathyroid hormone increased the mean osmotic fragility of red blood cells from newborn and adult rabbits, but showed the greater effect on those from newborns.

Similarly, the hormone stimulated to a much greater extent the Ca-ATPase, but not the Mg-ATPase in red blood cells from the newborn rabbits, in comparison with red blood cells from adult rabbits. Parathyroid hormone, which is greatly elevated in the blood of patients with chronic renal failure, may be one cause for the anaemia seen in these patients, and its effect, which is mediated by Ca-ATPase activity, is stronger on young red blood cells. Significant morphological changes in the young red blood cells, observed by scanning electron microscopy; were caused by parathyroid hormone.

\section{Introduction}

Anaemia associated with renal failure has been attributed to shortened red blood cell survival $(1,2)$. It has been shown (3) that erythrocyte survival is shortened by high levels of parathyroid hormone, and it was suggested that this is due to augmentation of calcium entry into the red blood cell, which affects their integrity. Parathyroid hormone caused a significant influx of ${ }^{45} \mathrm{Ca}$ into red blood cells and increased the median osmotic fragility of the cells. Furthermore, while not affecting erythrocyte $\mathrm{Na} / \mathrm{K}$-activated adenosine triphosphatase (ATPase), and Mg-dependent ATPase, it significantly stimulated the Ca-activated ATPase (3).

1) Part of this study was presented in the second congress of the International Society of Animal Clinical Biochemistry Israel 1985, and is due to be published as a proceeding in a special issue of Clinical Biochemistry.
The anaemic syndrome, which is common to uraemic patients, was explained by the destruction of red blood cells on the one hand and inhibition of erythropoiesis on the other hand (3-5). Parathyroid hormone, which is elevated in the blood of uraemic patients, was claimed to be one of the factors responsible for these phenomena (3). The present study examines the effect of $\mathrm{Ca}^{2+}$ and parathyroid hormone on the mean osmotic fragility of young and adult rabbits red cells and its relation to the activities of $\mathrm{Mg}$ - and Ca-activated ATPases.

\section{Materials and Methods}

As a model for this study we used blood from newborn and adult rabbits as a source of young and adult red blood cells, respectively. The blood was taken from newborns aged 1 to 48 hours, and from rabbits 3 to 5 months old. The osmotic fragility was evaluated by the method described by Parpart et al. (6). 
Two $\mathrm{ml}$ of blood were withdrawn into heparinized test tubes. The blood was diluted with $8.0 \mathrm{ml}$ isotonic phosphate buffered saline, $\mathrm{pH} 7.4$ and centrifuged for 5 minutes at $600 \mathrm{~g}$. The plasma and buffy coat were discarded, and the red blood cells were washed twice. The first wash was with $10 \mathrm{ml}$ saline containing $10 \mu \mathrm{mol} / \mathrm{l}$ ethylene diamine tetraacetic acid-di-sodium, (EDTA- $\mathrm{Na}_{2}$ ), adjusted to $\mathrm{pH}$ 7.4. The second wash was with $10 \mathrm{ml}$ of a solution containing $9.9 \mathrm{ml}$ phosphate-buffered saline and $0.1 \mathrm{ml}$ of $100 \mathrm{~g} / \mathrm{l}$ bovine serum albumin.

Each time the red blood cells were mixed with the solution by gentle inversion and centrifuged for 3 minutes at $600 \mathrm{~g}$. The washed packed cells were then suspended in phosphate-buffered saline to provide a haematocrit of 0.10 . The osmotic fragility curve was determined in triplicate in a series of tubes containing different salt concentrations ranging from 0 to $9 \mathrm{~g} / \mathrm{l} \mathrm{NaCl}$, $1 \mathrm{mmol} / \mathrm{l} \mathrm{CaCl}$ and $50 \mu \mathrm{l}$ of erythrocyte suspension to give a final volume of $1 \mathrm{ml}$. The reaction was carried out for 30 minutes in a shaking bath at $37^{\circ} \mathrm{C}$.

At the end of the incubation the cells were centrifuged and the absorbance of the supernatant was measured against water at $575 \mathrm{~nm}$ in a Pye-Unicam Sp 800-A spectrophotometer. The effect of $20 \mathrm{U} / \mathrm{ml}$ parathyroid hormone (Sigma Chemical Co. U.S.A.) on the osmotic fragility of the young and mature red blood cells was examined by the same procedure described above. The salt concentration at which a fraction of 0.50 of the erythrocytes were lysed was taken as an index of the median osmotic fragility according Parpart et al. (5).

Adenosine triphosphatase catalytic activity was measured in red blood cells ghosts, which were prepared according to the method described by Cha (7), with some modifications. Two $\mathrm{ml}$ blood were withdrawn into heparinized test tubes and cooled immediately on ice. The blood was diluted to $15 \mathrm{ml}$ with cold saline and centrifuged at $600 \mathrm{~g}$ for 10 minutes at $4{ }^{\circ} \mathrm{C}$. The cells were washed once with cold saline and then haemolysed in 15 $\mathrm{ml}$ of a cold solution containing $0.1 \mathrm{mmol} / 1$ Tris-HC1 buffer (pH 7.4) and $0.1 \mathrm{mmol} / \mathrm{l}$ EDTA- $\mathrm{Na}_{2}$. The haemolysate was centrifuged at $12000 \mathrm{~g}$ for 15 minutes at $4{ }^{\circ} \mathrm{C}$. The supernatant was discarded and the pellet was washed several times with the above haemolysing solution until the supernatant was colourless. The washed pellet was suspended in $5 \mathrm{ml}$ cold haemolysing solution for ATPase activity determination. Combined $\mathrm{Ca}$ - and Mg-dependent ATPase activity was determined according to the method of Cha (7), with some modifications. The reaction mixture contained $43 \mathrm{mmol} / 1$ histidine- $\mathrm{HC1}$ buffer, $\mathrm{pH} \mathrm{7.0,}$ $1 \mathrm{mmol} / \mathrm{l} \mathrm{CaCl}, 120 \mathrm{mmol} / 1 \mathrm{KCl}, 5 \mathrm{mmol} / 1 \mathrm{MgCl}_{2}$ and erythrocyte ghost suspension equivalent to $0.3-1 \mathrm{mg}$ protein. The reaction was started by the addition of $3 \mathrm{mmol} / \mathrm{l}$ ATP-Na $\mathrm{N}_{2}$. The final reaction volume was $1 \mathrm{ml}$.

The activity of Mg-dependent ATPase was determined in parallel, and the reaction mixture consisted of the same constituents except that $\mathrm{CaCl}_{2}$ was omitted and $1 \mathrm{mmol} / \mathrm{l}$ of ethyleneglycolbis-(amino ethyl ether), N, $\mathrm{N}^{1}$, tetraacetic acid (EGTA) was added. In order to study the effect of parathyroid hormone, 20 $\mathrm{U} / \mathrm{ml}$ of the hormone were added to the reaction mixture, which was placed in a shaking water bath at $37^{\circ} \mathrm{C}$ for 30 minutes; the reaction was stopped by the addition of $1 \mathrm{ml}$ of cold $200 \mathrm{~g} / 1$ trichloroacetic acid. The reactions were carried out in duplicate against blank controls which consisted of the same reagents, except that the red blood cells ghosts were added after addition of the trichloroacetic acid solution.

The reaction mixture was centrifuged in the cold at $3000 \mathrm{~g}$ for 10 minutes, and aliquots from the supernatant were taken for inorganic phosphate determination according to the method of Fiske \& Subbarow (8).

Ca-dependent ATPase activity was calculated by subtracting the activity of $\mathrm{Mg}$-dependent ATPase from the total activities of Ca- and Mg-ATPase.

Protein determination in the erythrocyte ghost suspension was carried out according to Lowry et al. (9).

The fraction of reticulocytes in each red blood cell suspension, prior to their treatment, was determined after vital staining with Nile blue.

Density distribution curves were prepared with a gravikit (Miles Yeda, Rehovot, Israel) according to the manufacturer's instructions. The kit consists of twenty different oily phthalates with densities ranging from 1.062 to $1.138 \mathrm{~kg} / \mathrm{l}$. Each oil was added to a depth of $10 \mathrm{~mm}$ in a separate haematocrit tube, filled up with the blood and spun for five minutes in a haematocrit centrifuge. The length of the packed red blood cells below and above the liquid was measured in each tube and a density curve was drawn (10).

In order to evaluate the effects of parathyroid hormone on red blood cell morphology in the presence of calcium, the cells were prepared and incubated with calcium and parathyroid hormone as described previously (3). The packed cells were then fixed in $10 \mathrm{~g} / \mathrm{l}$ glutaraldehyde for examination by a scanning electron microscope.

Statistical evaluation was performed according to Student's test and the paired t-test. The results are presented as mean \pm SEM.

\section{Results}

The osmotic fragility curve and the mean osmotic fragility of red blood cells from newborn and mature rabbits are given in table 1 and figure 1 . Whereas the mean osmotic fragility of cells from adult rabbits was represented by $5.10 \pm 0.17 \mathrm{~g} / 1 \mathrm{NaCl}$, the value for newborns was $3.90 \pm 1.01 \mathrm{~g} / 1(\mathrm{p}>0.001)$. The value for red blood cells from adult rabbits in the presence of $20 \mathrm{U} / \mathrm{ml}$ parathyroid hormone was $5.48 \pm 0.10$ $\mathrm{g} / \mathrm{l}$, a difference of $0.38 \pm 0.06 \mathrm{~g} / 1(\mathrm{p}<0.001)$, representing an increase of $7.8 \pm 1.24 \%$. On the other hand, mean lysing concentration of $\mathrm{NaCl}$ for erythrocytes from newborn rabbits in the presence of

Tab. 1. The effect of parathyroid hormone on mean osmotic fragility of red blood cells from adult and newborn rabbits $(\mathrm{g} / \mathrm{l} \mathrm{NaCl}$, mean $\pm \mathrm{SEM})$.

\begin{tabular}{|c|c|c|c|c|c|c|}
\hline 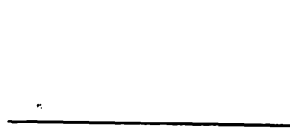 & $\mathrm{N}$ & $\begin{array}{l}\text { Without } \\
\text { parathyroid } \\
\text { hormone }\end{array}$ & $\begin{array}{l}\text { With } \\
\text { parathyroid } \\
\text { hormone }\end{array}$ & $\begin{array}{l}\text { Paired t-test } \\
\pm \text { parathyroid } \\
\text { hormone }\end{array}$ & $\begin{array}{l}\text { Difference } \\
\text { of mean osmotic } \\
\text { fragility }\end{array}$ & $\begin{array}{l}\text { Difference } \\
\text { in } \%\end{array}$ \\
\hline $\begin{array}{l}\text { Adults } \\
\text { Newborns }\end{array}$ & $\begin{array}{l}7 \\
6\end{array}$ & $\begin{array}{l}5.10 \pm 0.17 \\
3.90 \pm 0.10\end{array}$ & $\begin{array}{l}5.48 \pm 0.10 \\
4.54 \pm 0.09\end{array}$ & $\begin{array}{l}p<0.001 \\
p<0.001\end{array}$ & $\begin{array}{l}0.38 \pm 0.06 \\
0.64 \pm 0.08\end{array}$ & $\begin{array}{r}7.81 \pm 1.24 \\
16.7 \pm 0.66\end{array}$ \\
\hline Level of significance & & $\mathrm{p}<0.001$ & $\mathrm{p}<0.001^{\circ}$ & & $0.001<\dot{\mathrm{p}}<.0 .01$ & $p<0.001$ \\
\hline
\end{tabular}




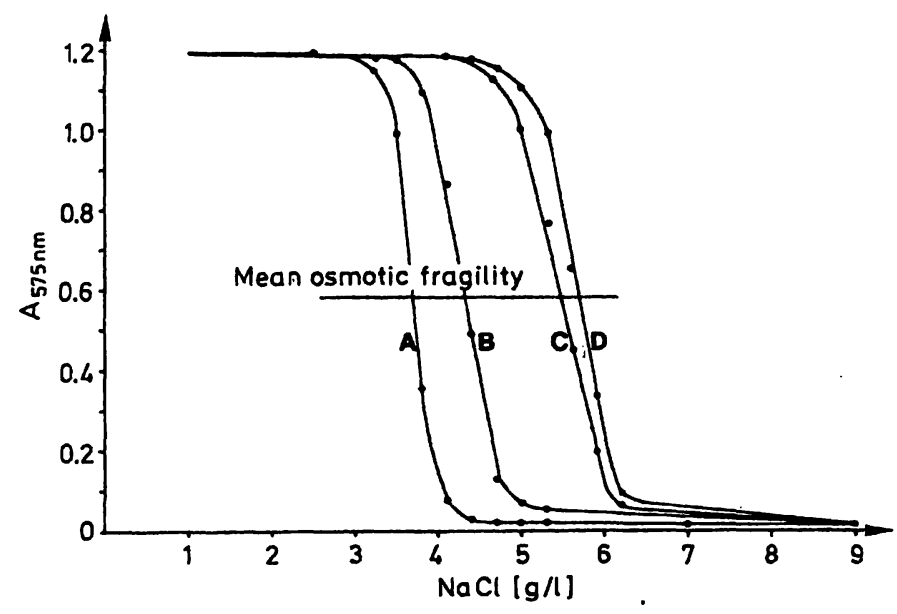

Fig. 1. The osmotic fragility and mean osmotic fragility of erythrocytes from newborn and mature rabbits in the absence and presence of parathyroid hormone (one experiment).

a - erythrocytes from newborn rabbits - parathyroid hormone

b - erythrocytes from newborn rabbits + parathyroid hormone $(20 \mathrm{U} / \mathrm{ml})$

c - erythrocytes from mature rabbits - parathyroid hormone

d - erythrocytes from mature rabbits + parathyroid hormone $(20 \mathrm{U} / \mathrm{ml})$

$20 \mathrm{U} / \mathrm{ml}$ parathyroid hormone was $4.54 \pm 0.09 \mathrm{~g} / \mathrm{l}$, an increase of $0.64 \pm 0.08 \mathrm{~g} / \mathrm{l}(\mathrm{p}<0.001)$, representing an increase of $16.7 \pm 0.06 \%$.

The catalytic activities and the effect of parathyroid hormone on the activities of Ca-ATPase are shown in table 2 . While not significantly different, the activ- ity ( $P_{i}$ liberated) of this enzyme in cells from adult rabbits was $0.487 \pm 0.039 \mu \mathrm{mol} / 30 \mathrm{~min} \cdot \mathrm{mg}$ protein, and was somewhat higher in the newborn rabbits with activities of $0.621 \pm 0.110 \mu \mathrm{mol} / 30 \mathrm{~min} \cdot \mathrm{mg}$ protein. The stimulation by parathyroid hormone however was much greater in cells from newborn rabbits, in comparison with those from adults. While the enzyme activity in the red blood cells from mature rabbits was stimulated from $0.487 \pm 0.039$ to 0.671 $\pm 0.066 \mu \mathrm{mol} / 30 \mathrm{~min} \cdot \mathrm{mg}$ protein (an increase of $36.5 \pm 4.5 \% ; \mathrm{p}<0.01$ ), it was stimulated in the cells from newborn rabbits from $0.621 \pm 0.110$ to 1.352 $\pm 0.175 \mu \mathrm{mol} / 30 \mathrm{~min} \cdot \mathrm{mg}$ protein (an increase of $127.2 \pm 22.0 \% ; \mathrm{p}<0.01$ ).

The activities and the effect of parathyroid hormone on $\mathrm{Mg}$-ATPase activity are given in table 3 . The activity of this enzyme in the red blood cells from adult rabbits was significantly lower than in the cells from newborn rabbits. While the activity in the absence of parathyroid hormone in the red blood cells from adult rabbits was $0.298 \pm 0.046$, it was $0.599 \pm$ $0.100 \mu \mathrm{mol} / 30 \mathrm{~min} \cdot \mathrm{mg}$ protein in the young cells $(p<0.02)$. The presence of parathyroid hormone in the medium only slightly stimulated the activity of the enzyme. The stimulation of the enzyme by parathyroid hormone was similar in both groups of red blood cells.

There was a significant $(p<0.01)$ difference in the mean fraction of reticulocytes in the blood of newborn $(0.184 \pm 0.046)$ and mature rabbits $(0.040 \pm$ 0.016) (tab. 4). If results from newborn and adult

Tab. 2. The effect of parathyroid hormone on Ca-ATPase activity ( $\dot{P}_{i}, \mu$ mol/30 min $\cdot \mathrm{mg}$ protein), mean \pm SEM of erythrocyte ghosts from adult and newborn rabbits.

\begin{tabular}{llllllr}
\hline & $\mathrm{N}$ & $\begin{array}{l}\text { Without } \\
\text { parathyroid } \\
\text { hormone }\end{array}$ & $\begin{array}{l}\text { With } \\
\text { parathyroid } \\
\text { hormone }\end{array}$ & $\begin{array}{l}\text { Paired t-test } \\
\pm \text { parathyroid } \\
\text { hormone }\end{array}$ & $\begin{array}{l}\text { Difference of } \\
\text { Ca-ATPase }\end{array}$ & $\begin{array}{l}\text { Difference } \\
\text { in \% }\end{array}$ \\
\hline Adults & 6 & $0.487 \pm 0.039$ & $0.671 \pm 0.066$ & $0.001 \mathrm{p}<0.01$ & $0.184 \pm 0.030$ & $36.5 \pm 4.5$ \\
Newborns & 6 & $0.621 \pm 0.110$ & $1.352 \pm 0.175$ & $0.001 \mathrm{p}<0.01$ & $0.731 \pm 0.124$ & $127.2 \pm 22.0$
\end{tabular}

Tab. 3. The effect of parathyroid hormone on Mg-ATPase activity $\left(P_{i}, \mu\right.$ mol/30 min $\cdot$ mg protein), mean \pm SEM of erythrocyte ghosts from adult and newborn rabbits.

\begin{tabular}{llllll}
\hline & $\mathrm{N}$ & $\begin{array}{l}\text { Without } \\
\text { parathyroid } \\
\text { hormone }\end{array}$ & $\begin{array}{l}\text { With } \\
\text { parathyroid } \\
\text { hormone }\end{array}$ & $\begin{array}{l}\text { Difference of } \\
\text { Mg-ATPase }\end{array}$ & $\begin{array}{l}\text { Difference } \\
\text { in \% }\end{array}$ \\
\hline $\begin{array}{l}\text { Adults } \\
\text { Newborns }\end{array}$ & 6 & $0.298 \pm 0.046$ & $0.333 \pm 0.047$ & $0.035 \pm 0.005$ & $13.0 \pm 2.7$ \\
& 6 & $0.599 \pm 0.100$ & $0.661 \pm 0.099$ & $0.062 \pm 0.029$ & $12.6 \pm 4.8$ \\
Level of significance & & $\mathrm{p}=0.02$ & $0.01<\mathrm{p}<0.02$ & n.s. & n.s. \\
\hline
\end{tabular}


Tab. 4. Reticulocyte count (fraction of erythrocytes) in adult and newborn rabbits.

\begin{tabular}{lllllll}
\hline & $\mathrm{N}$ & Mean & Range & SD & SEM & $\begin{array}{l}\text { Significance of } \\
\text { difference }\end{array}$ \\
\hline Adults & 5 & 0.040 & $0.005-0.085$ & 0.035 & 0.016 & $0.01<\mathrm{p}<0.02$ \\
Newborns & 5 & 0.184 & $0.070-0.300$ & 0.103 & 0.046 & \\
\hline
\end{tabular}

red blood cells were calculated together, there was a significant positive correlation $(r=0.86 ; \mathrm{p}<0.01)$ between the fraction of the reticulocytes in the blood and the relative stimulation by parathyroid hormone of Ca-ATPase activity. Whenever the correlation coefficient was calculated for each group alone, the values were lower $(r=0.11$ for the adult cells and 0.78 for the young ones) and insignificant.

Two adult rabbit blood samples were examined and both showed the same density distribution curve for the red blood cells. Two newborn samples were also identical. The density distribution curves (fig. 2) showed that, compared with newborn samples, adult rabbit blood contains a higher proportion of cells of higher specific gravity. In the adults more than $90 \%$ of the cells had a density over $1.102 \mathrm{~kg} / \mathrm{l}$, whereas only $3 \%$ of the young cells had a density greater than $1.102 \mathrm{~kg} / \mathrm{l}$. This indicates that the red blood cells from adult rabbits are older and longer circulating than the cells from the newborns.

Figure $3 \mathrm{a}$ shows the shape of red blood cells from adult rabbits, which served as the control. Except for a slight irregularity in their shape, they appeared completely normal.

Addition of parathyroid hormone did not cause any structural change (fig. 3 b). Control erythrocytes from young rabbits also appeared quite normal (fig. $3 \mathrm{c}$ ). On the other hand, addition of parathyroid hormone to these cells induced marked echinocytosis (fig. $3 \mathrm{~d}$ ) as well as a pronounced degree of red cell aggregation.

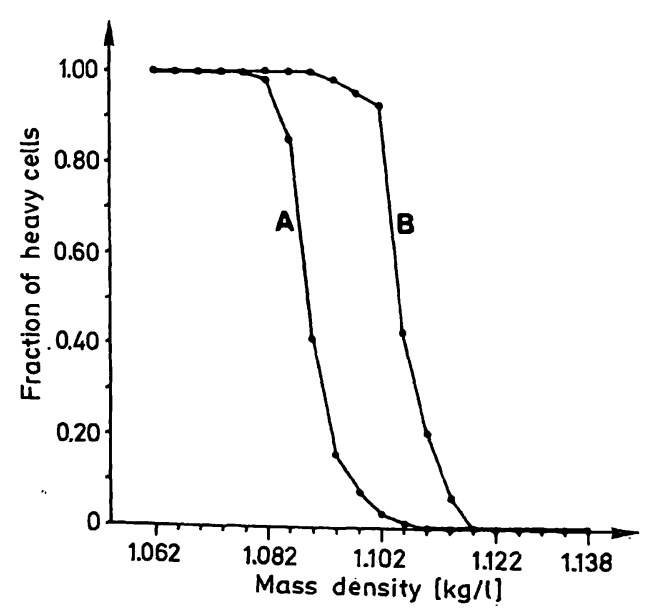

Fig. 2. Density distribution curves of red blood cells from newborn (a) and adult (b) rabbits.

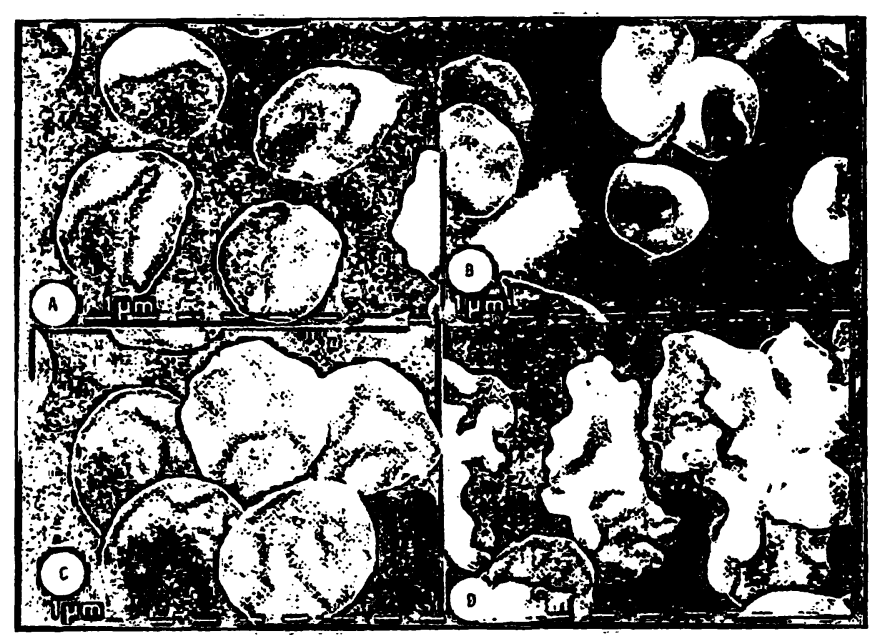

Fig. 3. a Control adult rabbit's red blood cells. The surface and shape is well preserved.

b Adult rabbit's red blood cells after incubation with parthyroid hormone. The structure and shape are well preserved.

c Young rabbit's red blood cells without parathyroid hormone. Except for a slight anisocytosis, the cells appear normal.

d Young rabbit's red blood cells after incubation with parathyroid hormone. The change in shape is evident. There is marked echinocytosis.

\section{Discussion}

It has been shown that parathyroid hormone greatly increased the mean osmotic fragility of human red blood cells in hypotonic salt solution. The hormone also stimulated the activity of the membrane enzyme, Ca-ATPase, and caused ${ }^{45} \mathrm{Ca}$ influx into the cells (3). The present study demonstrated that erythrocytes from newborn rabbits are less susceptible to osmotic lysis in comparison to erythrocytes from adult ones. Furthermore, it showed that parathyroid hormone caused a much greater increase in the osmotic fragility of red blood cells from newborn rabbits, compared with cells from adult rabbits. The activity of $\mathrm{Ca}$ ATPase in red blood cells from newborn rabbits was stimulated to a greater extent by parathyroid hormone than that of cells from adult rabbits. Erythrocytes are a target for parathyroid hormone activity, which exerts its effects by changing $\mathrm{Ca}$ metabolism by enhancing $\mathrm{Ca}$ penetration into the cells. The present study clearly demonstrated that the degree of the parathyroid hormone effect is a function of Ca-ATPase activity in red blood cells. Cẹlls from newborn 
rabbits, which showed greater Ca-ATPase activity, also showed greater stimulation by the hormone, compared with cells from adult rabbits. It seems, therefore, that parathyroid hormone, which is greatly elevated in the blood of patients with chronic renal failure, and which was suggested as a cause of anaemia seen in these patients, affects young cells more than mature ones $(3,4)$. Levels of parathyroid hormone used in this study are comparable to levels seen in the blood of chronic renal failure patients on dialysis. Furthermore, the observed effects of parathyroid hormone on the agglutination of red blood cells were mimicked by ultrafiltrates obtained from sera of uraemic patients (11).

It is reasonable to postulate that since the pregnancy period of rabbits is significantly shorter than the lifetime of circulating erythrocytes, the blood of newborn rabbits contains a relatively larger proportion of young cells in comparison to adult rabbits. Indeed, this is evident from the significantly greater reticulocyte population in the blood of the newborn rabbits than in adult animals. While the mean reticulocyte level of adult rabbit blood was 0.040 , it was 0.184 in the newborn. The normal rabbit blood reticulocyte level of about 0.040 is greater than that for human blood (12). Also the difference between the density distribution curves of the red blood cells from newborn and adult rabbits clearly demonstrated that erythrocytes from newborns consisted of much younger cells than the erythrocytes from adult rabbits, which makes it a suitable model for our study.

The activities of some erythrocyte enzymes can serve as indicators of erythrocyt age. Two commonly used enzymes are aspartate aminotransferase and glucose6-phosphate dehydrogenase. The activities of these enzymes were found to be lower in older red blood cells than in young ones $(13,14)$. It is possible that the activities of other red cell enzymes, including $\mathrm{Ca}$ ATPase, also decrease with age. This could explain the different activities of Ca-ATPase seen in red blood cells from mature rabbits compared with those from newborns. Since the effect of parathyroid hormone on the osmotic fragility of red blood cells is mediated by the activity of Ca-ATPase and entry of $\mathrm{Ca}^{2+}$ into the cells, this explains the fact that red blood cells from newborn rabbits are affected to a greater extent by the hormone.

It is of interest that although the levels of both CaATPase and Mg-ATPase were higher in cells from newborn rabbits, the stimulation by parathyroid hormone of Ca-ATPase was $127.2 \pm 22.0 \%$ and only $12.6 \pm 4.8$ of $\mathrm{Mg}$ ATPase, once again indicating the role of $\mathrm{Ca}$ and Ca-ATPase in the induction of increased osmotic fragility.
There was a good correlation $(r=0.86 ; p<0.01)$ between the stimulation by parathyroid hormone of Ca-ATPase activity and the reticulocyte population in the blood. This relationship, however, was only seen when all blood samples from mature and newborn rabbits was calculated, which reflects the result that the stimulation of Ca-ATPase was stronger in newborn than in cells from a mature rabbit. But whenever the correlation coefficients were calculated from each group alone, the values obtained were smaller and insignificant, which may indicate that the changes of the Ca-ATPase activities were correlated not only with the fraction of the reticulocytes, but were also characteristic of the whole red cell population in the investigated samples.

The cellular events linking an increase in osmotic fragility of the red blood cell and the parathyroid hormone-mediated increase in calcium influx are not evident. Several possibilities exist. First, increased calcium influx into the erythrocyte $(15,16)$ and stimulation of Ca-ATPase $(16,17)$, utilize ATP, which results in ATP depletion. Recent studies suggest that ATP may have a direct effect on membrane flexibility by affecting membrane-associated structural proteins $(18,19)$. Thus, ATP depletion may affect membrane stability and lead to cell destruction.

Second, red blood cells possess a membrane skeleton located at the membrane-cytosol surface, the major component being spectrin-actin $(20,21)$. This cytoskeletal network participates in several membrane functions, including control of shape, viscoelastic properties, surface topology and membrane stability $(20-22)$. An increase in the calcium concentration of the erythrocyte causes cross-linking of membrane proteins of intact cells, and it has been suggested that the intrinsic cross-linking of membrane proteins is a key signal for the removal of red blood cells from the circulation (23). It is possible that by enhancing calcium influx into the cells, the hormone causes cross-linking of membrane proteins, thereby affecting membrane structure and stability. The fact that parathyroid hormone affects erythrocytes is supported by the finding of filamentous extensions with the scanning electron microscope (3) and the agglutination of the cells (11).

The anaemia seen in patients with chronic renal failure seems to be due to inhibition of erythropoesis (4) and enhanced destruction of erythrocytes (3). The present study suggests that young red blood cells are destroyed more rapidly than mature ones, and that this may occur not only in the blood, but also most probably at the site of their synthesis, namely the bone, before their appearance in the blood. 


\section{References}

1. Desforges, J. F. \& Dawson, J. P. (1958) Arch. Intern. Med. $101,326-332$.

2. Eklund, S. G., Johanson, S. V. \& Stranberg, O. (1971) Acta Med. Scand. 190, 435-443.

3. Bogin, E., Massry, S. G., Levi, J., Djaldetti, M., Bristol, G. \& Smith, J. (1982) J. Clin. Invest. 69, 1017-1025.

4. Malachi, Z., Bogin, E., Gafter, U. \& Levi, J. (1986) Nephron 42, 52-57.

5. Meytes, D., Bogin, E., Ma, A., Dukes, P. P. \& Massry, S. G. (1981) J. Clin. Invest. 67, 1263-1269.

6. Parpart, A. K., Lorenz, P. B., Parpart, E. R., Gregg, J. R. \& Chase, A. M. (1947) J. Clin. Invest. 26, 636-640.

7. Cha, Y. N., Shin, B. C. \& Lee, K. S. (1971) J. General Physiol. 57, 202-215.

8. Fiske, C. H. \& Subbarow, Y. (1925) J. Biol. Chem. 66, $375-400$

9. Lowry, O., Rosebrough, N. J., Farr, A. L. \& Randall, R. I. (1951) J. Biol. Chem. 193, 265-275.

10. Danon, D. \& Marikovsky, J. (1964) J. Lab. Clin. Med. 64, $668-674$

11. Earon, Y., Blum, M. \& Bogin, E. (1983) Clin. Chim. Acta 135, 253-262.
12. Schalm, O. W. (1965) Veterinary Hematology $2^{\text {nd }}$ ed. Lea and Febiger, Philadelphia.

13. Sass, M. D. \& Spear, P. W. (1961) J. Lab. Clin. Med. 58, $568-591$.

14. Turner, B. M., Fisher, R. A. \& Harris, H. (1974) Clin. Chim. Acta. 50, 85-95.

15. Reed, P. W. (1976) J. Biol. Chem. 254, 3489-3494.

16. Taylor, D., Baker, R. \& Hochstein, P. (1977) Biochem. Biophys. Res. Commun. 76, 205-211.

17. Sarkadi, B. (1980) Biochim. Biophys. Acta 604, 159-190.

18. Birchmeir, W. \& Singer, S. J. (1977) J. Cell. Biol. 73, 647659.

19. Lutz, H. V., Lin, S. C. \& Palek, I. (1977) J. Cell. Biol. 73, $548-560$.

20. Steck, T. L. (1974) J. Cell. Biol. 62, 1-19.

21. Lux, S. E. (1979) Semin. Hematol. 16, $21-51$.

22. Kirkpatrick, F. H. (1976) Life Sci 19, 1-17.

23. Siefering, G. E. \& Lonard, L. (1978) In: Erythrocytes Membranes. Recent Clinical and Experimental Advances (Kruckeberg, S., Eaton, J. \& Brewer, G., eds.) Alan R. Liss . Inc, New York pp. 25-32.

\author{
Professor E. Bogin \\ Dept. Biochemistry \\ Kimron Veterinary Institute \\ Tel-Aviv University \\ School of Medicine \\ P. O. Box 12 \\ Bet-Dagan, Israel 50200
}

